\title{
Off-pump grafting of the circumflex artery with pedicled retro-aortic right internal thoracic artery
} graft

\author{
Revascularização da artéria marginal com uso da artéria torácica interna direita pediculada \\ retroaórtica sem circulação extracorpórea
}

Walter J. GOMES, George B. TAVARES, Jaime I. JARAMILLO, Francisco A. ALVES, José Miguel G. TORRIJOS, Roberto CATANI, Enio BUFFOLO

RBCCV 44205-726

\section{Abstract}

Objective: Off-pump coronary artery bypass surgery (OPCAB) has demonstrated to provide reduction of cardiovascular events and mortality. Also the bilateral use of the internal thoracic arteries (ITAs) can offer additional benefits, improving survival. We present the technique of OPCAB using both pedicled ATI grafts, with the right ITA (RITA) routed retro-aortically through the transverse sinus, to revascularize the branches of the circumflex artery $(\mathrm{Cx})$.

Method: Twenty-six patients underwent OPCAB with bilateral ATI grafts have been studied, where the left ATI (LITA) was used to revascularize the left anterior descending artery (LAD) and the pedicled RITA, routed through the transverse sinus, anastomosed to the branches of the $\mathbf{C x}$. Twenty-one patients were male and five female, the age ranging between 42 and 74 years. The morbidities observed in this cohort were previous myocardial infarction in $18(69 \%)$ patients, diabetes mellitus in $\mathbf{1 0}(\mathbf{3 8 \%})$, renal failure in four (7.7\%) and AIDS in one (3.8\%) patient.

Results: No patient presented ECG changes or enzymatic rise in the postoperative one. The grafts per patient varied from 2 to 4 (average 3.0 grafts/patient). No cases of sternal infection or dehiscence were observed. One patient had a stroke on the $4^{\circ} \mathrm{PO}$ day and died. The postoperative hospital stay varied between 3 to 12 days (average $5.8 \pm 2.0$ days). No late deaths or cardiovascular events were recorded.

Conclusions: This technique, making possible the offpump grafting of the circumflex artery branches using the pedicled RITA, potentially enhances the benefits of the coronary artery bypass surgery.

Descriptors: Myocardial revascularization. Internal mammary-coronary artery anastomosis. Mammary arteries. Extracorporeal circulation

Resumo

Objetivo: A revascularização miocárdica (RM) sem circulação extracorpórea (CEC) tem demonstrado proporcionar redução da mortalidade e da morbidade. Também o uso bilateral das artérias torácicas internas (ATIs) pode oferecer benefício adicional, conferindo maior sobrevida.

Work performed in the Hospital Geral de Pirajussara and in the Hospital São Paulo.

Partially presented at the 31 st National Congress of Cardiac Surgery in Curitiba, PR, in April 2004.

Correspondence address: Walter J. Gomes. Rua Borges Lagoa, 1080 cj 608. São Paulo, SP. CEP 04038-002. Tel. (11) 5572-6309. Fax (11) $5571-8785$.

E-mail wjgomes.dcir@epm.br 
Apresentamos técnica de revascularização miocárdica utilizando ambas ATIs pediculadas, com a ATI direita (ATID), passada retroaórtica, para revascularizar os ramos da artéria circunflexa (ACx), sem CEC.

Método: Foram estudados 26 pacientes submetidos à RM sem CEC, com enxertos bilaterais de ATIs, sendo a ATI esquerda (ATIE) dirigida para a artéria descendente anterior (ADA) e a ATID, pediculada através do seio transverso, anastomosada aos ramos da ACx. Foram analisados 21 pacientes do sexo masculino e cinco do feminino, a idade variou entre 42 e 74 anos. As co-morbidades associadas foram infarto do miocárdio prévio em $18(69 \%)$ pacientes, diabetes mellitus em $10(38 \%)$, insuficiência renal em quatro $(7,7 \%)$ e AIDS em um $(3,8 \%)$ doente.

Resultados: Nenhum paciente apresentou alteração de

\section{INTRODUCTION}

Recent studies have demonstrated that off-pump coronary artery bypass surgery (OPCAB) is safe and efficient, presenting results better than the conventional technique using a cardiopulmonary bypass (CPB), resulting in a reduction of mortality and morbidity [1-6]. The utilization of the $\mathrm{CPB}$ is associated with complex systemic inflammatory responses and neurologic alterations, which contribute significantly to the occurrence of perioperative complications.

Additionally, observation studies over the last decade showed that the bilateral use of the internal thoracic arteries (ITAs) can offer additional benefits to patients, improving survival and a lower incidence of cardiovascular events when compared to single ITA grafts. This significant benefit to survival occurs when both ITA grafts are placed in the left coronary system and are seen even in high-risk patients such as diabetics, elderly patients and those with left ventricular dysfunction [7-10].

However, in spite of the advantages offered by the bilateral use of ITA in coronary artery bypass surgery $(\mathrm{CABG})$, their use is still limited due to the great difficulties of this technique

However, to aggregate the advantages offered by the combination of these two techniques could offer patients additional advantages reducing risks and improving the late results.

We present our initial experience with OPCAB using both pedicled internal thoracic arteries, with the right ITA(RITA), retro-aortic routed through the transverse sinus to revascularize the branches of the circumflex artery $(\mathrm{Cx})$.
ECG ou elevação enzimática no pós-operatório. As pontes por paciente variaram de 2 a 4 (média de 3,0 pontes/paciente). Não houve infecção ou deiscência esternal. Um paciente apresentou AVC no $4^{\circ} \mathrm{PO}$ e faleceu. A permanência hospitalar pós-operatória variou entre 3 e 12 dias (média 5,8 $\pm 2,0$ dias). A duração do seguimento tardio foi de 2 a 38 meses. Não houve eventos cardiovasculares ou óbitos tardios.

Conclusões: Esta técnica, possibilitando a revascularização dos ramos da artéria circunflexa com enxerto de ATI direita pediculada, sem uso de CEC, potencialmente amplia os benefícios da cirurgia de revascularização miocárdica.

Descritores: Revascularização miocárdica. Artérias mamárias. Anastomose mamário-coronária. Circulação extracorpórea.

\section{METHOD}

\section{Patients}

Twenty-six patients, who underwent OPCAB surgery using bilateral pedicled ITA grafts were analysed, with the left internal thoracic artery (LITA) anastomosed to the anterior descending artery (ADA) and the RITA routed retroaortically through of transverse sinus and anastomosed to the branches of the Cx. Twenty-one male and five female patients were studied with ages ranging between 42 and 74 years and a mean of $54.8 \pm 9.0$ years. The associated comorbidities were prior myocardial infarction in $18(69 \%)$ patients, diabetes mellitus in $10(38 \%)$, renal insufficiency in four $(7.7 \%)$, two of whom were on chronic dialysis, peripheral arterial disease in three $(11.5 \%)$ and AIDS in one $(3.8 \%)$ patient.

The ejection fraction, measured by echocardiography (Teicholz method) varied between $42 \%$ and $73 \%$ (mean of $64.9 \pm 8.7 \%)$. All the patients were being treated in the outpatients' clinical. The study protocol was approved by the Institution's Ethics Committee.

\section{Technique}

The anesthesia was induced using sufentanil, midazolam and pancuronium and maintained using the same drugs by means of infusion pumps. Plasmatic expansion was performed at the start of the surgery using crystalloid solutions and synthetic colloids to optimize the pre-load. Inotropic support, when necessary, was achieved with the use of dobutamine administrated by infusion pumps. Anticoagulation was accomplished with a single dose of $400 \mathrm{IU} / \mathrm{kg}$ of heparin. 
The surgeries were performed by medium sternotomy and both internal thoracic arteries were dissected skeletonized using a meticulous technique for clipping and sectioning of arterial branches, from the root to the bifurcation. The LITA was anastomosed to the ADA and the RITA to the marginal artery in all cases.

The strategy was to always anastomose the LITA to the ADA first and after to revascularize the posterior descending artery, allowing the medial luxation of the heart to follow to expose the lateral wall. Additional grafts of saphenous vein or right gastroepiploic artery were used for the revascularization of the posterior descending artery. Diagonal arteries were always revascularized when possible with a sequential graft of the LITA or saphenous vein.

The RITA was sectioned generally near to the distal termination before the bifurcation. A 4-0 cotton thread was tied on its distal end and it was pulled using a Satinsky clamp routed retro-aortically through the transverse sinus, bringing the RITA to the lateral wall.

After this, the heart was moved medially to expose the lateral wall and marginal artery, which was achieved using a single Lima stitch and an Octopus ${ }^{\circledR} 3$ suction stabilizer (Medtronic, Inc ${ }^{\circledR}$ ) positioned on an OctoBase ${ }^{\circledR}$ retractor (Medtronic, Inc $\mathbb{R}$ ). Occlusion of the coronary artery was obtained using a proximal tourniquet of 4-0 polypropylene thread passing through a malleable silicon tube. A distal tourniquet was not utilized to avoid additional injury to the coronary artery, nor were intracoronary shunts used in the procedure. The anastomosis of the RITA to the marginal artery was performed with a continuous suture using a single 7-0 polypropylene thread (Figures 1 and 2 ).

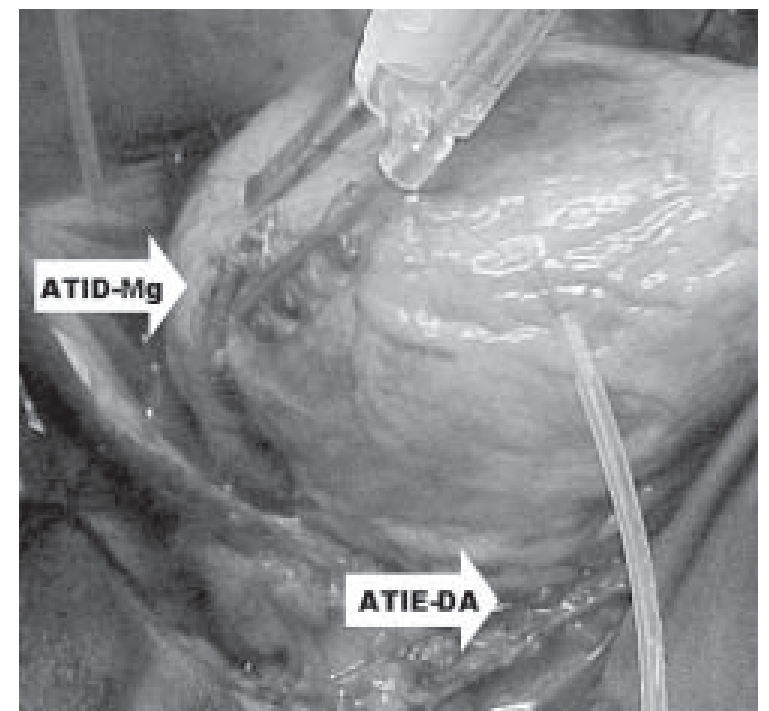

Fig. 1 - Anastomosis of the right internal thoracic artery (RITA) with the marginal artery $(\mathrm{Mg})$ and the left internal thoracic artery (LITA) with the anterior descending coronary artery (AD)

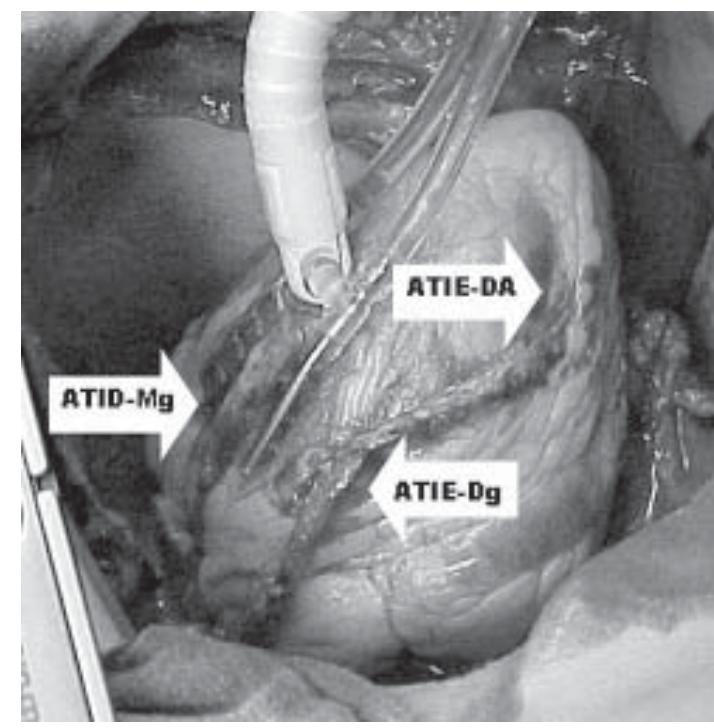

Fig. 2 - Anastomosis of the right internal thoracic artery (RITA) with the marginal artery $(\mathrm{Mg})$. Also there are details of the sequential anastomoses of the left internal thoracic artery (LITA) with the anterior descending coronary artery $(\mathrm{AD})$ and the diagonal branch $(\mathrm{Dg})$

In the last three cases, an intraoperative blood recuperation system was used.

\section{RESULTS}

In the intraoperative period, all patients tolerated heart luxation to perform the anastomoses well, with six patients needing inotropic support with dobutamine to perform the anastomoses to the marginal artery. No patient presented ECG changes or enzymatic increases in the postoperative period. No patient required mediastinal re-exploration for bleeding. The total number of grafts performed was 78 and the number of grafts per patient varied from 2 to 4 (an average of 3.0 grafts/patient). The LITA was used for sequential revascularization of the ADA and the diagonal artery in four patients. The right gastroepiploic artery was used to revascularize the posterior descending artery in three cases and in the others segments of saphenous vein were used reversely. No cases of infection or sternal dehiscence were observed, nor were significant postoperative complications. Only one patient suffered a stroke on the 4th postoperative day, evolving to a severe cerebral infarction and death on the 21 st postoperative day (mortality of 3.8\%). This patient had undergone lateral aortic clamping to repair the proximal anastomosis of the saphenous vein. One patient suffered infection of the incision used for the removal of the saphenous vein. The postoperative hospital stay varied between 3 and 12 days, averaging $5.8 \pm 2.0$ days.

The duration of the late follow up was from 2 to 38 months (mean of 12.3 months) and was completed by all patients. 
No patient presented with any heart events or needed percutaneous coronary intervention and there were no late deaths.

Three patients underwent postoperative cinecoronariography, one because of the decision of the cardiologist and two because of thoracic discomfort. The grafts of the bilateral ITA were pervious.

\section{COMMENTS}

Undoubtedly, the greatest contributions to coronary artery bypass grafting surgery in the last decades were the introduction of the off-pump technique and the demonstration of the results over the long-term with the use of the bilateral ITA.

Recent researches demonstrated that OPCAB surgery significantly improves the mortality and morbidity rates in all subgroups, but especially in patients with a higher risk of operative death [1-6]. Moreover, the hospital stay is reduced with the necessity of less hospital resources and consequently a lower cost, when compared with the conventional technique [11-14].

The use of bilateral ITA grafts can offer additional benefits to the patient, improving survival and reducing the incidence of cardiovascular events, when compared with single ITA grafts. The benefit of a significantly improved survival rate occurs when both ITA grafts are placed pedicled to the left coronary system, that is, when the LITA is anastomosed to the ADA and the RITA to the branches of the Cx. These benefits are also seen in high risk patients such as diabetic patients and the elderly and those with left ventricular dysfunction $[7-10,15]$. Particularly in diabetic patients, the bilateral use of the ITAs improves survival and reduces the necessity of future revascularization procedures $[9,16]$.

Recently, large studies have confirmed that the pedicled RITA routed through the transverse sinus and anastomosed to the branches of the $\mathrm{Cx}$, has an excellent angiographic patency over the long term, comparable to the LITA anastomosed to the ADA [17]. The technique using the pedicled RITA routed through the transverse sinus to revascularize the marginal artery was proposed by PUIG et al. [18], at the beginning of the 1980s. However, the RITA when used to revascularize the right coronary artery presents worse results [19].

Previous anatomic studies demonstrated that any coronary artery can be reached by pedicled ITA grafts [20]. URA et al. [21], in a prospective study demonstrated that the pedicled RITA can reach the branches of the $\mathrm{Cx}$ in more than $90 \%$ of cases. In our experience, with the use of the technique of skeletonized dissection this problem was minimized. Sometimes the suture was ended with evident tension which disappeared when the medially dislocated heart was replaced in its original position.
Skeletonization of the ITA is essential in the application of this technique, allowing the attainment of sufficiently long pedicles to anastomose to the marginal artery. Moreover, skeletonization maintains the arterial vascular connections of the sternum, avoiding devascularization and the consequent risk of sternal dehiscence [22]. Thus, it is possible to use this technique in high risk patients, such as diabetics, chronic renal failure patients and even, as in one case of our series, in patients with AIDS. In the past, the bilateral use of ITA grafts was associated to an increase of sternal complications in diabetic patients [23], which was improved by changing the dissection technique to the skeletonization technique.

In the operative technique, the revascularization order is also a determining factor of its success. In this series, the first artery to be revascularized was always the ADA, followed the posterior descending or diagonal artery and, lastly, the branches of the Cx. This is necessary because, during luxation of the heart to expose the lateral wall and the closing of the marginal artery, the other heart segments need to be revascularized to tolerate and to compensate for the fall in the heart output.

Another important factor related to the quality of this technique is the utilization of stabilizers, in this case the Octopus ${ }^{\circledR 3}$ suction stabilizer (Medtronic, Inc) was used, which makes immobilization of the coronary artery and better quality anastomoses possible. Recently, the use of the Starfish ${ }^{\circledR}$ positioner system (Medtronic, Inc ${ }^{\circledR}$ ) made medial dislocation of the heart possible with obvious attenuation of hemodynamic alterations.

The advantages of this method are: 1) possibility of performing $\mathrm{OPCAB}$ surgery; 2 ) by using retro-aortic routing of the RITA there are no ITA grafts crossing the medial line, reducing the potential for complications in the case of necessary reoperations; 3 ) it can be associated with the already established method of LITA-DA anastomosis and 4) the RITA in situ can be used to revascularize arteries of the left coronary system. Although the use of free RITA grafts in $\mathrm{Y}$ or as free grafts constitutes a tactical option, there is a necessity of additional anastomoses with a possible increase in technical defects and graft failure, especially in patients with advanced atherosclerotic disease or in patients with small corporal surface and vessel of small calibers.

This initial series shows that, in selected patients, the strategy of OPCAB surgery, using the RITA anastomosed to the marginal artery is possible with technical success. Moreover, the additional use of the right gastroepiploic artery to revascularize the posterior descending artery makes OPCAB surgery possible using only pedicled arterial grafts. Theoretically, this strategy of coronary artery bypass grafting is near to the ideal model in quality, due to the increase of the clinical benefits translated by the superiority of the arterial grafts over venous grafts and its utilization 
without the use of cardiopulmonary bypasses. The next step towards the ideal procedure is to perform this technique through minimum incisions using video systems or assisted by robots.

\section{CONCLUSION}

This technique makes revascularization of the branches of the circumflex artery with a pedicled right internal thoracic artery graft possible using off-pump coronary artery bypass surgery and potentially increases the benefits of coronary artery bypass surgery.

\section{BIBLIOGRAPHIC REFERENCES}

1. Gobran SR, Goldman S, Ferdinand F, Wertan MA, Trace C, Grunkemeier GL et al. Outcomes after usage of a quality initiative program for off-pump coronary artery bypass surgery: a comparison with on-pump surgery. Ann Thorac Surg. 2004;78(6):2015-21.

2. Reston JT, Tregear SJ, Turkelson CM. Meta-analysis of shortterm and mid-term outcomes following off-pump coronary artery bypass grafting. Ann Thorac Surg. 2003;76(6):1510-5.

3. Buffolo E, Andrade JCS, Branco JN, Teles CA, Aguiar LF, Gomes WJ. Coronary artery bypass grafting without cardiopulmonary bypass. Ann Thorac Surg. 1996;61(1):63-6.

4. Magee MJ, Jablonski KA, Stamou SC, Pfister AJ, Dewey TM, Dullum MK et al. Elimination of cardiopulmonary bypass improves early survival for multivessel coronary artery bypass patients. Ann Thorac Surg. 2002;73(4):1196-203.

5. Cleveland Jr JC, Shroyer AL, Chen AY, Peterson E, Grover FL. Off-pump coronary artery bypass grafting decreases riskadjusted mortality and morbidity. Ann Thorac Surg. 2001;72(4):1282-9.
6. Angelini GD, Taylor FC, Reeves BC, Ascione R. Early and midterm outcome after off-pump and on-pump surgery in Beating Heart Against Cardioplegic Arrest Studies (BHACAS 1 and 2): a pooled analysis of two randomised controlled trials. Lancet. 2002;359(9313):1194-9.

7. Lytle BW, Blackstone EH, Sabik JF, Houghtaling P, Loop FD, Cosgrove DM. The effect of bilateral internal thoracic artery grafting on survival during 20 postoperative years. Ann Thorac Surg. 2004;78(6):2005-14.

8. Buxton BF, Komeda M, Fuller JA, Gordon I. Bilateral internal thoracic artery grafting may improve outcome of coronary artery surgery: risk-adjusted survival. Circulation. 1998;98(119 suppl):I11-6.

9. Endo M, Nishida H, Tomizawa Y, Kasanuki H. Benefit of bilateral over single internal mammary artery grafts for multiple coronary artery bypass grafting. Circulation. 2001;104(18):2164-70.

10. Gerola LR, Puig LB, Moreira LF, Cividanes GV, Gemha GP, Souto RC et al. Right internal thoracic artery through the transverse sinus in myocardial revascularization. Ann Thorac Surg. 1996;61(6):1708-13.

11. Nathoe HM, van Dijk D, Jansen EW, Suyker WJ, Diephuis JC, van Boven WJ et al. A comparison of on-pump and offpump coronary bypass surgery in low-risk patients. N Engl J Med. 2003;348(5):394-402.

12. Puskas JD, Thourani VH, Marshall JJ, Dempsey SJ, Steiner MA, Sammons BH et al. Clinical outcomes, angiographic patency, and resource utilization in 200 consecutive off-pump coronary bypass patients. Ann Thorac Surg. 2001;71(5):1477-84.

13. Lobo-Filho JG, Leitão MCA, Lobo-Filho HG, Soares JPH, Magalhães GA, Leão-Filho CSC et al. Cirurgia de revascularização coronariana esquerda sem CEC e sem manuseio da aorta em pacientes acima de 75 anos. Rev Bras Cir Cardiovasc. 2002;17(3):208-14.

14. Lima RC, Escobar MAS, Lobo-Filho JG, Diniz R, Saraiva A, Césio A et al. Resultados cirúrgicos na revascularização do miocárdio sem circulação extracorpórea. Análise de 3.410 pacientes. Rev Bras Cir Cardiovasc. 2003;18(3):261-7.

15. Dallan LA, Oliveira SA, Lisboa LA, Platania F, Jatene FB, Iglézias JCR et al. Revascularização completa do miocárdio com uso exclusivo de enxertos arteriais. Rev Bras Cir Cardiovasc. 1998;13(3):187-93.

16. Lytle BW, Blackstone EH, Loop FD, Houghtaling PL, Arnold $\mathrm{JH}, \mathrm{Akhrass} \mathrm{R}$ et al. Two internal thoracic artery grafts are better than one. J Thorac Cardiovasc Surg. 1999;117(5):855-72.

17. Ascione R, Underwood MJ, Lloyd CT, Jeremy JY, Bryan AJ, Angelini GD. Clinical and angiographic outcome of different surgical strategies of bilateral internal mammary artery grafting. Ann Thorac Surg. 2001;72(3):959-65. 
18. Puig LB, França Neto L, Rati M, Ramires JA, Luz PL, Pileggi $\mathrm{F}$ et al. A technique of anastomosis of the right internal mammary artery to the circumflex artery and its branches. Ann Thorac Surg. 1984;38(5):533-4.

19. Chow MS, Sim E, Orszulak TA, Schaff HV. Patency of internal thoracic artery grafts: comparison of right versus left and importance of vessel grafted. Circulation. 1994;90(5 Pt 2):II129-32.

20. Salm TJ, Chowdhary S, Okike ON, Pezzella AT, Pasque MK. Internal mammary artery grafts: the shortest route to the coronary arteries. Ann Thorac Surg. 1989;47(3):421-7.
21. Ura M, Sakata R, Nakayama Y, Arai Y, Oshima S, Noda K et al. Technical aspects and outcome of in situ right internal thoracic artery grafting to the major branches of the circumflex artery via the transverse sinus. Ann Thorac Surg. 2001;71(5):1485-90.

22. Henriquez-Pino JA, Gomes WJ, Prates JC, Buffolo E. Estudo anatômico da artéria torácica interna aplicado à cirurgia cardiovascular. Rev Bras Cir Cardiovasc. 1997;12(1):83-8.

23. Grossi EA, Esposito R, Harris LJ, Crooke GA, Galloway AC, Colvin SB et al. Sternal wound infections and use of internal mammary artery grafts $\mathrm{J}$ Thorac Cardiovasc Surg. 1991;102(3):342-7. 